\title{
Diabetes Associated to Atherosclerosis Risk Factors in Patients of Family Health Unity
}

\author{
Polyane Medeiros Alves ${ }^{1}$, Raiane dos Santos Pereira1, Ariel Gustavo Letti², \\ Álvaro Luís Müller da Fonseca ${ }^{3}$ \\ ${ }^{1}$ Universidade do Estado da Bahia (UNEB), Senhor do Bonfim, Brazil \\ ${ }^{2}$ Departamento de Educação (DEDC7), Universidade do Estado da Bahia (UNEB), Senhor do Bonfim, \\ Brazil \\ ${ }^{3}$ Laboratory of Immunology, Departamento de Educação (DEDC7), Universidade do Estado da Bahia \\ (UNEB), Senhor do Bonfim, Brazil \\ Email: alfonseka@gmail.com
}

Received 12 March 2015; accepted 19 April 2015; published 27 April 2015

Copyright (C) 2015 by authors and Scientific Research Publishing Inc.

This work is licensed under the Creative Commons Attribution International License (CC BY).

http://creativecommons.org/licenses/by/4.0/

c) (†) Open Access

\begin{abstract}
Cardiovascular diseases, including atherosclerosis, are important causes of death among diabetics. Features of diabetes mellitus (DM) associated with atherogenic risk factors are discussed by a cross-sectional study. It was evaluated 432 families attended by Basic Family Health Unities (FHU), registered at Family Health Program (HIPERDIA) at borough Alto da Maravilha in Senhor do Bonfim, Bahia, Brazil. Among eligible patients, 50 (8.4\% of the total) were included in diabetic group (DB), and 80 (9.4\% of the total) in the non-diabetic group (NDB). The majority was women (90/ 130 ) in the age range $48-77$. The diabetic group showed a high prevalence among analyzed variables, such as hypertension $(\mathbf{7 4 . 0 \% )}$ ) and obesity $(\mathbf{4 6 . 0 \% )}$. Significant differences were not found among lipoprotein cholesterol concentrations comparing the DB and NDB groups. The correlation analysis showed significant differences among LDL-C-DB and CT-DB $(p<0.0001)$, LDL-NDB and CT-NDB ( $<$ 0.0001), LDL-NDB and TG-NDB ( $p=0.0034)$, and CT-NDB and TG-NDB ( $p=0.0001)$. Diabetic and healthy individuals do not present significant differences in the lipid profiles. By the way, the diabetic and health individuals can not present significant differences in the lipid profile, however, probably there are differences in the quality of the lipoprotein molecules between DB and NDB and a divergent tendency of the disease progression, such as a higher disposition to atherosclerosis development in DB. These patients with potential risk to development atherosclerosis or aggravation of diabetes must have more attention about Family Health Program.
\end{abstract}

\section{Keywords}

Diabetes Mellitus, Risk Factors, Atherosclerosis, Family Health Care

How to cite this paper: Alves, P.M., dos Santos Pereira, R., Letti, A.G. and da Fonseca, Á.L.M. (2015) Diabetes Associated to Atherosclerosis Risk Factors in Patients of Family Health Unity. Open Journal of Preventive Medicine, 5, 177-185.

http://dx.doi.org/10.4236/ojpm.2015.54021 


\section{Introduction}

Among the cardiovascular diseases, the coronary artery disease (CAD) is the most prevalent and represents the biggest cause of death in developed countries. Data from DATASUS show that in Brazil there are about one million hospital internments occurring every year due to cardiovascular diseases [1] [2].

Some characteristics and habits, known as risk factors, may increase the chance of a person to develop atherosclerotic disease. Among the factors are an elevated level of total cholesterol and low density lipoprotein (LDL), and a low level of high density lipoprotein (HDL), arterial hypertension (HAS), tobacco use, obesity, sedentariness, old age and diabetes mellitus.

The diabetes mellitus (DM) is a metabolic disorder, whose main characteristics are disturbances in carbohydrate and in the processing of both fats and proteins, resulting from defects in the secretion, on the action of the insulin or in both. The DM is grouped into two subtypes: one is related to autoimmune origin and also related to a deficiency of insulin, called type $1 \mathrm{DM}$, and the other one results from a complicated physiopathological process triggered by pregnant and secondary insulin resistance, referred to as type $2 \mathrm{DM}$. In the diabetic population, the CAD features drive the patients to have the greatest morbimortality when compared with a healthy population [3].

The atherosclerotic process is emphasized in diabetic individuals due to long exposure to hyperglycemia and hyperinsulinemia, in addition to the insulin resistance, which drive to cellular alterations in every stage of the process [4].

Additionally, the diabetic individuals present a higher risk to cardiovascular disease, and they have a worse prognosis too, with smaller surviving at short time, a bigger risk of disease aggravation and a worst response to the treatment [5]. The atherosclerosis in diabetics is more severe, appears with greater frequency, and occurs earlier when compared with healthy individuals, increasing the risk of cardiac infarction in those diabetic individuals [6].

This work approaches the diabetes development, analyzing its prevalence and estimating its association to known atherosclerosis risk factors in a population sample of patients under the care of the Basic Family Health Unities in Senhor do Bonfim, Bahia, Brazil.

\section{Methods}

\subsection{Studied Population}

Along May and June of 2012 a observational transversal study was made, in which 432 families were randomly chosen, representing 1/5 from 2161 families registered in HIPERDIA (monitoring system of hypertension and diabetes that affect the patients covered by the "Plano Nacional de Reorganização e Atenção à Hipertensão Arterial e ao Diabetes mellitus" inside the Family Healthy Program [Programa de Saúde da Família—PSF] supported by the Federal Government of Brazil) at the Family Healthy Unity (Unidade de Saúde da Família-USF) at Alto da Maravilha in Senhor do Bonfim, Bahia, Brazil. The 432 families were separated in two arrangements (1 and 2) with 216 families each.

After the verification of the medical cards, the patients were selected following the inclusion and exclusion criteria to diabetic group (DB) from the previous arrangement 1 and non-diabetics (NDB) from arrangement 2. The medical cards analyzes were made along all period in USF rooms, after the authorization and order from $\mathrm{Mu}-$ nicipal Healthy Department. The other analyzes was made in the Immunology Laboratory at DEDC 7-UNEB.

\subsection{Arrangement and Analysis Criteria}

The selection of 593 allocate able individuals from the 878 that compound the first arrangement (compound by 126 families) according the inclusion and exclusion criteria. The individuals with 18 years and above were selected which present laboratorial exams to plasmatic lipoproteins (C-LDL, C-HDL, CT and TG) and that present diabetes diagnostic; patients bellow 18 years were excluded and those ones that do not have exams to C-LDL or CT. The DB group was compound by 50 patients that were selected by convenience from those 593 individuals.

In the same way, 848 individuals were put apart from the second arrangement with 216 families too, and 80 patients were able according to the inclusion and exclusion criteria. Individuals from 18 years old were included, without diabetes diagnostic and that present laboratory exams to plasmatic lipoproteins (C-LDL, C-HDL, CT 
and TG); individuals that follow the same exclusion criteria to the anterior group were excluded and, obviously, those ones that present diabetes diagnostic. To constitute the NDB group, 80 patients were selected by convenience.

The total cholesterol level (TC) of the patients was classified according to the "III Diretrizes Brasileiras sobre Dislipidemias e Diretriz de Prevenção da Aterosclerose do Departamento de Aterosclerose da Sociedade Brasileira de Cardiologia" [7] and present the follow measurements goals:

- Desirable: $\mathrm{TC}<200 \mathrm{mg} / \mathrm{dL} ; \mathrm{LDL}<130 \mathrm{mg} / \mathrm{dl} ; \mathrm{HDL} \geq 40 \mathrm{mg} / \mathrm{dL}$ and $\mathrm{TG}<150 \mathrm{mg} / \mathrm{dL}$;

- Borderline: TC between $200-239 \mathrm{mg} / \mathrm{dL}$; LDL between $130-159 \mathrm{mg} / \mathrm{dL}$ and TG $<150 \mathrm{mg} / \mathrm{dL}$;

- High Risk: TC $\geq 240 \mathrm{mg} / \mathrm{dL} ; \mathrm{LDL} \geq 160 \mathrm{mg} / \mathrm{dL} ; \mathrm{HDL}<40 \mathrm{mg} / \mathrm{dL}$ and $\mathrm{TG} \geq 200 \mathrm{mg} / \mathrm{dL}$.

\subsection{Collection and Data Analysis}

The clinical profile data were taken from analysis of patients' medical cards and from the application data register of the HIPERDIA program. Patients from both groups (DB and NDB) subscribe the Free Consentient and Clarified Term (FCCT), which enable the use of the medical card data and HIPERDIA register data.

The following data were taken from the medical cards: age, gender, plasmatic lipoprotein values (TC, C-LDL, C-HDL, and TG), smoking habit, sedentary occupation (sedentariness), alcohol ingestion (alcoholism), overweight/ obesity and cardiovascular previous events. The last laboratory exams of both groups (DB and NDB) were taken into consideration.

This work does not present any ethical relevant conflicts. The research project was approved by the Ethical Research Commit of UNEB (CEP-UNEB), number 57679 (CAE 03310612.6.0000.0057).

\subsection{Statistical Analysis}

The data collected were statistically addressed to determine the distribution type (if Gaussian or not) using D'Agostino and Pearson method on GraphPad Prism 5.4 software. Whenever the distribution of Gaussian was encountered, a parametrical test was adopted ( $\mathrm{t}$ of Student) to make the inferential statistical comparison between averages, and cases non-Guassian, non-parametrical tests were done (Mann-Whitney) to compare the averages.

Collinear correlation tests (Pearson and Spearman) were performed to evaluate the power and the direction of the relation among the variables, every two ones to each group.

\section{Results}

The 50 diabetic patients selected represent $8.4 \%$ the total sorted individuals (593), from which 38 present type 2 diabetes and 12, type 1 diabetes. The 80 non diabetic patients consist $9.4 \%$ from the total ones (848) sorted and considered able to the research.

It was observed that most of the diabetic individuals were between 63 and 77 years old $(42.0 \%)$ and the non diabetic ones between 48 and 62 years $(31.2 \%)$. The majority of the sampled population was compounded by women in both DB and NDB groups (Table 1).

Table 1. DB and NDB patients' distribution according age and gender.

\begin{tabular}{ccccccc}
\hline Age (years) & M n (DB) & M n (NDB) & Fn (DB) & F n (NDB) & Total n (\%) DB & Total n (\%) NDB \\
\hline $18-32$ & 0 & 3 & 0 & 4 & $0(0)$ & $7(8.7)$ \\
$33-47$ & 4 & 6 & 0 & 14 & $4(8)$ & $20(25.0)$ \\
$48-62$ & 7 & 6 & 11 & 19 & $18(36)$ & $25(31.2)$ \\
$63-77$ & 4 & 7 & 17 & 16 & $21(42)$ & $7(14)$ \\
$78-92$ & 1 & 2 & 6 & 3 & $50(100)$ & $5(6.3)$ \\
Total & 16 & 24 & 34 & 56 & & $80(100)$ \\
\hline
\end{tabular}

DB - diabetics; NDB — non diabetics; $\mathrm{n}$ - number of individuals; $\mathrm{M}$ - masculine; $\mathrm{F}$ - $\mathrm{feminine.}$ 
The diabetic patients present clinical profile with higher percentages to almost every characteristic, except to infarction. It was notable that $37 / 50(74.0 \%)$ of DB present hypertension 23/50 (46.0\%) and also obesity/overweight features (Table 2).

When compared with the lipoprotein values there weren't any significant differences $(p<0.05)$ between DB and NDB groups. In the same way, the comparison of lipoprotein values subgroups in every profile desirable, borderline and undesirable (high risk) also do not present any significant differences. Significant positive linear correlations were found between the lipid markers to DB and NDB groups. Among the DB there was a strong positive linear correlation between TC and LDL markers $(p<0.0001)$ (Table 3). In this same group, TG and HDL markers do not present any significant linear correlations with the other markers. In NDB group there was strong positive linear correlations among TC and LDL $(\mathrm{p}<0.0001)$, TC and TG $(\mathrm{p}=0.0001)$, TG and LDL $(\mathrm{p}=$ 0.0034) (Table 4).

The ratios for LDL-C/HDL-C; TC/HDL-C and TG/HDL-C did not show significant differences between the groups DB and NDB.

Table 2. Clinical profile of the DB and NDB groups.

\begin{tabular}{cccc}
\hline Characteristic & DB n (\%) & NDB n (\%) & Total n (\%) \\
\hline Feminine & $34(68.0) ;$ & $56(70.0) ;$ & $90(69.2) ;$ \\
Masculine & $16(32.0)$ & $24(30.0)$ & $62(47.7)$ \\
Hypertension & $37(74.0)$ & $25(31.2)$ & $25(19.2)$ \\
Smoking & $16(32.0)$ & $9(11.2)$ & $4(3.0)$ \\
Alcoholism & $3(6.0)$ & $1(1.3)$ & $26(20.0)$ \\
Obesity/overweight & $23(46.0)$ & $3(3.7)$ & $32(24.6)$ \\
Sedentariness & $21(42.0)$ & $11(13.7)$ & $1(0.7)$ \\
Infarct & $0(0.0)$ & $80(100 ; 61.5)$ & $130(100 ; 100.0)$ \\
Total $\mathrm{n}(\%)$ & $50(100 ; 38.5)$ &
\end{tabular}

DB — diabetics; NDB — non diabetics; $\mathrm{n}$ —number of individuals.

Table 3. Linear correlation data analyze between the lipoprotein values in DB.

\begin{tabular}{|c|c|c|c|c|}
\hline & LDL (DB) & TC (DB) & TG (DB) & HDL (DB) \\
\hline LDL (DB) & & $\begin{array}{c}\mathrm{n}=39 \\
\mathrm{r}=0.8972\left({ }^{2}\right) \\
\mathrm{p}=0.0001^{*}\end{array}$ & $\begin{array}{c}\mathrm{n}=41 \\
\mathrm{r}=-0.1257\left({ }^{1}\right) \\
\mathrm{p}=0.4336 \\
(\mathrm{~ns})\end{array}$ & $\begin{array}{c}\mathrm{n}=39 \\
\mathrm{r}=0.2594\left({ }^{1}\right) \\
\mathrm{p}=0.1108 \\
(\mathrm{~ns})\end{array}$ \\
\hline TC (DB) & $\begin{array}{c}\mathrm{n}=39 \\
\mathrm{r}=0.8972\left(^{2}\right) \\
\mathrm{p}=0.0001^{*}\end{array}$ & & $\begin{array}{c}\mathrm{n}=46 \\
\mathrm{r}=0.1219\left(^{1}\right) \\
\mathrm{p}=0.4195 \\
(\mathrm{~ns})\end{array}$ & $\begin{array}{c}\mathrm{n}=39 \\
\mathrm{r}=0.3094\left({ }^{1}\right) \\
\mathrm{p}=0.0553 \\
(\mathrm{~ns})\end{array}$ \\
\hline TG (DB) & $\begin{array}{c}\mathrm{n}=41 \\
\mathrm{r}=-0.1704\left(^{2}\right) \\
\mathrm{p}=0.2867 \\
(\mathrm{~ns})\end{array}$ & $\begin{array}{c}\mathrm{n}=46 \\
\mathrm{r}=0.1792\left(^{2}\right) \\
\mathrm{p}=0.2334 \\
(\mathrm{~ns})\end{array}$ & & $\begin{array}{c}\mathrm{n}=40 \\
\mathrm{r}=-0.2794\left({ }^{1}\right) \\
\mathrm{p}=0.0808 \\
(\mathrm{~ns})\end{array}$ \\
\hline HDL (DB) & $\begin{array}{c}\mathrm{n}=39 \\
\mathrm{r}=0.1751\left({ }^{2}\right) \\
\mathrm{p}=0.2863 \\
(\mathrm{~ns})\end{array}$ & $\begin{array}{c}\mathrm{n}=39 \\
\mathrm{r}=0.2659\left(^{2}\right) \\
\mathrm{p}=0.1018 \\
(\mathrm{~ns})\end{array}$ & $\begin{array}{c}\mathrm{n}=40 \\
\mathrm{r}=-0.2794\left({ }^{1}\right) \\
\mathrm{p}=0.0808 \\
(\mathrm{~ns})\end{array}$ & \\
\hline
\end{tabular}

$\mathrm{n}=$ number of pars; $\mathrm{r}=$ correlation coefficient; $\mathrm{p}=$ significant level; $\left({ }^{1}\right)$ Spearman linear correlation; $\left({ }^{2}\right)$ Pearson linear correlation; ns $=$ non significant correlation; ${ }^{*}=$ significant correlation; $\mathrm{DB}=$ diabetic group. 
Table 4. Linear correlation data analyze between the lipoprotein values in NDB.

\begin{tabular}{|c|c|c|c|c|}
\hline & LDL (NDB) & CT (NDB) & TG (NDB) & HDL (NDB) \\
\hline LDL (NDB) & & $\begin{array}{c}\mathrm{n}=72 \\
\mathrm{r}=0.9032\left({ }^{1}\right) \\
\mathrm{p}<0.0001^{*}\end{array}$ & $\begin{array}{c}\mathrm{n}=75 \\
\mathrm{r}=0.3084\left({ }^{1}\right) \\
\mathrm{p}=0.0034^{*}\end{array}$ & $\begin{array}{c}\mathrm{n}=34 \\
\mathrm{r}=0.09536\left(^{1}\right) \\
\mathrm{p}=0.5916 \\
(\mathrm{~ns})\end{array}$ \\
\hline CT (NDB) & $\begin{array}{c}\mathrm{n}=72 \\
\mathrm{r}=0.9086\left(\left(^{2}\right)\right. \\
\mathrm{p}<0.0001^{*}\end{array}$ & & $\begin{array}{c}\mathrm{n}=76 \\
\mathrm{r}=0.424\left({ }^{1}\right) \\
\mathrm{p}=0.0001^{*}\end{array}$ & $\begin{array}{c}\mathrm{n}=31 \\
\mathrm{r}=0.2977\left({ }^{1}\right) \\
\mathrm{p}=0.1039 \\
(\mathrm{~ns})\end{array}$ \\
\hline TG (NDB) & $\begin{array}{c}\mathrm{n}=75 \\
\mathrm{r}=0.3345\left(^{2}\right) \\
\mathrm{p}=0.0034^{*}\end{array}$ & $\begin{array}{c}\mathrm{n}=76 \\
\mathrm{r}=0.4247\left(^{2}\right) \\
\mathrm{p}=0.0001^{*}\end{array}$ & & $\begin{array}{c}\mathrm{n}=33 \\
\mathrm{r}=-0.1094\left({ }^{1}\right) \\
\mathrm{p}=0.5456 \\
(\mathrm{~ns})\end{array}$ \\
\hline HDL (NDB) & $\begin{array}{c}\mathrm{n}=34 \\
\mathrm{r}=0.1325\left(^{2}\right) \\
\mathrm{p}=0.4550 \\
(\mathrm{~ns})\end{array}$ & $\begin{array}{c}\mathrm{n}=31 \\
\mathrm{r}=0.2977\left(^{2}\right) \\
\mathrm{p}=0.1039 \\
(\mathrm{~ns})\end{array}$ & $\begin{array}{c}\mathrm{n}=33 \\
\mathrm{r}=-0.1094\left(^{1}\right) \\
\mathrm{p}=0.5456 \\
(\mathrm{~ns})\end{array}$ & \\
\hline
\end{tabular}

$\mathrm{n}=$ number of pars; $\mathrm{r}=$ correlation coefficient; $\mathrm{p}=$ significant level; $\left({ }^{1}\right)$ Spearman linear correlation; $\left({ }^{2}\right)$ Pearson linear correlation; ns $=$ non significant correlation; ${ }^{*}=$ significant correlation; $\mathrm{NDB}=$ non diabetic group.

\section{Discussion}

The major indexes of morbidity and mortality in the world are associated to atherosclerotic disease, which in accordance with some authors [8] is the most common abnormality sited in arteries as a primary result of two basic processes: the cholesterol accumulation inside the foam cells and the smooth muscle cells proliferation at the arterial intima tunic, which result in inflammation. The population misinformation about the associated risk factors and atherosclerosis, still are high; and consequently the hospitalization numbers caused by CAD complications become higher too, resulting in more expenses to Brazilian Health Programs.

Based on physiopathological observations in humans and animals, some studies suggest the hypothesis that the atherosclerotic disease is an organism response to the tissue injury concerned in the endothelial dysfunction, and has been observed that oxidised low density lipoproteins (oxLDL) are one of the main factors involved in the tissue lesion trigger [9]. The critical risk factors associated to atherosclerosis, as dyslipidaemias, hypertension, smoking, sedentariness, obesity, and diabetes mellitus (which is an independent factor to the atherosclerosis according to some authors), deserves special attention along the sampling and anamneses procedures of potential affected individuals, at same time that the identification of the carriers of risk factors, may help to minimise the complications resulting from atherosclerosis.

$\mathrm{DM}$ is an import public health problem that compromises the life quality and survival of the people. The mortality caused by cardiovascular events is increasing among diabetics and is related to the disease development stage, as well as to other cardiovascular risk factors' aggregation (obesity, hypertension, dyslipidemia, and others), showing whatever the therapeutic strategy to DM is important to take into consideration the occurrence of these other factors [10]. Some studies reveal that people who present diabetes in less than 10 years have cardiovascular risk comparable to someone that presents previous coronary problem, and that the diabetic women more than 10 years have a much higher risk [11]. The type $1 \mathrm{DM}$ patients have weight augmentation due to the insulin treatment associated with the dietary pattern alterations and sedentary habits, and present strong relation to a lipid profile more propitiously to atherosclerosis development together with LDL and triglycerides index increasing and HDL rate decreasing [12]. The insulin resistance associated to lipotoxicity helps to understand the cause of the accelerated velocity development of the cardiovascular diseases in type 2 DM patients [13].

As a result of this research, Table 1 shows that the major part of individuals in DB group (42.0\%) present age range from 63 to 77 years, which is consonant with the Brazilian Diabetes Association data establishing that DM affects $7.6 \%$ of the Brazilian population between 30 and 69 years, bearing to about $20.0 \%$ of population with age over 70 years. The results still show that the majority of individuals from both groups, DB and NDB, are compounded by women $34 / 50(68.0 \%)$ and $56 / 80(70.0 \%)$, respectively, and therefore the women proportion in each group is similar. According to the Diabetes Consensus data [10], the DM prevalence is correspondent between women and men and the results of some studies [14] confirm this assertion and reveal disappearance of 
minimal differences that can exist between the sexes, along the age advance. From the 50 DM diagnosed individuals, $38(76.0 \%)$ present type $2 \mathrm{DM}$, showing a tendency already anticipated by some authors [15], and $90.0 \%$ of the diabetes cases are of type 2.

$\mathrm{DM}$ affects millions of people and the CAD is the main cause of death among these individuals. The patients with type $1 \mathrm{DM}$, due to the insulin treatment, present weight increasing and, in general, sedentariness, resulting in a lipid profile propitious to atherosclerosis development. The type $2 \mathrm{DM}$ patients present the same risk factors to atherosclerotic disease that the general population, forcing the idea from some authors [16], that diabetes, in several times, coexist with obesity, hypertension and dyslipidaemias. The authors' assertion may be corroborated by this study because $74.0 \%$ of DB also presents HAS and $46.0 \%$ have obesity condition (Table 2 ). The DB patients also presented a bigger prevalence regarding to almost all habit risk associated if compared with NDB. These habits (smoking, alcoholism, sedentariness, cardiovascular antecedents and obesity) in association to high LDL rate and low HDL rate may drive to atherosclerotic disease aggravation. Second some authors [17], the high atherogenic lipoprotein indexes, including Very Low Density Lipoprotein (VLDL) and the LDL, are in general feature connected to low HDL indexes. The HDL have high anti atherogenic potency, mainly due to its capacity to transport lipids, specially cholesterol ester from peripheral tissues to the liver through the reverse cholesterol transport way (RCT), apart from offering anti-oxidised protection, mediate the cholesterol efflux, inhibit the expression of cellular adhesion molecules and leukocyte activation.

DM is directly linked to dyslipidemias. The dyslipidemias arise from physiological changes that result in serum values above or below the desirable for CT (total cholesterol), LDL-C (LDL cholesterol), TG (triglycerides), relations CT/HDL-C and LDL-C/HDL-C and for the fraction non-HDL-C (non-HDL cholesterol), but mainly when HDL-C (HDL cholesterol) is below the desirable [18]-[20]. HDL-C is one of the most promising indicators to determine risk of atherosclerotic cardiovascular disease [21]. There is an increased risk with the growth of LDL-C, non-HDL-C, CT, and the biggest ratio CT/HDL-C has a positive linear relationship with Atherosclerotic cardiovascular disease, as well as LDL-C, especially in elderly patients. The increase in the rates of CT, LDL-C, non-HDL-C, apoB, TC/HDL-C, LDL-C/HDL-C, and apoB/apoA-I are associated with the presence of atherosclerotic plaque [21] [22], but highlighting the ratio CT/HDL-C. By de way, the non-HDL-C could be usefulness as a risk marker of cardiovascular disease [23], and non-HDL-C would be more related to apoB than with the LDL-C, having the same predictive value that these lipoproteins. Therefore, the increased level of HDL-C is associated with the decrease in the thickening of the intima of carotid average in patients with type $2 \mathrm{DM}$ and atherosclerosis [24].

In despite that this study do not present any significant difference among the ratios between lipoproteins markers, and there are few subsides to determine the real cause of that in this case; tendency to develop cardiovascular diseases in both groups is inferred because the lifestyle are similar, including diet, smoking, sedentariness and weight gain along the time life, however, this tendency probably is greater to the DM group [25] [26].

For evaluation of particle size of LDL, the use of the TG/HDL-C ratio [27]-[29] is more significant than other ratios (TC/HDL-C and LDL-C/HDL-C), i.e. ratios TG/HDL-C $>1.0$ and is a reliable estimate for determining the presence of small dense LDL particles and whose concentration increases represent an increased risk of cardiovascular events [30]. In turn, the ratios TC/HDL-C and LDL-C/HDL-C are indicative of risk of cardiovascular event, being the greater the risk the more ratios are distanced positively of 1.0.

There are no significant difference between the TG/HDL-C ratios between the DB and NDB, however in DB the ratios are higher (minimum 1.3 and maximum 11.5) than in NDB (minimum 0.9, maximum 9.4), indicating a larger number of individuals with small and dense LDL particles in the Group DB and greater tendency to aggravation of the disease in this study.

In the groups analysed, the comparison of markers values (LDL, HDL, TC and TG) also did not present any significant differences between DB and NDB. The comparison among the subgroups according to the lipid profile also does not present any significant differences. These results which may be explained because the level of C-LDL (cholesterol of LDL) in individuals with type $2 \mathrm{DM}$ in general is similar to the one found in normal population [30] [31], however, that the quality of the LDL molecule is different between diabetics and not diabetics persons [27]. In diabetics LDL is smaller and denser, which makes it more atherogenic. The people with type $1 \mathrm{DM}$ that present controlled glucose rate in blood circulation, probably also have lipid levels similar to the healthy people; the glycemic index control being fundamental in the interference of lipid concentrations of patients with type $1 \mathrm{DM}[32]$.

The linear correlation tests performed with the lipid markers do not present any significant correlation among 
HDL and the others markers in both DB and NDB groups. In despite, HDL have inverse relation with DM a negative correlation among HDL and other markers would be expected, in the same time the increase of HDL marker occurs there must be a reduction of other markers ones, and when there are HDL rate decrease there must be an increase in the rate of others ones [27] [30] [33]. The HDL have great potential to induce the production of nitric oxide (NO), which is a strong ally to fight against the atherosclerotic disease, because it acts in the reduction of the oxidation of incorporated particles to LDL and in addition, acts at particles incorporation through the reverse cholesterol transport, driving to its oxidation in the liver [33] [34].

In DB group the LDL and TC markers, the correlation was positive (Table 3), demonstrating what already was expected, once that the LDL is a TC fraction. However there was no significant correlation between LDL and TG in DB group, this correlation shows tendency to be negative due to the probable incorporation of TG in LDL. The correlation between LDL with TC and LDL with TG, in NDB group, was positive (Table 4), what also already was expected in so far as in NDB the incorporation of those lipoproteins particles in LDL, theoretically is reduced. The non variance among the lipoproteins, as well as the results obtained after the linear correlation tests between the studied groups, DB and NDB, also may be related to the fact that those diabetic patients are covered by HIPERDIA program, which cares and monitoring periodically those hypertensive and diabetic individuals and gives the adequate treatment to these diseases, besides it's probable that the medicines used to treat the DM help, in some way, the maintenance of the desirable levels of plasmatic lipoproteins.

\section{Conclusion}

Both diabetic patients and healthy ones can present the same lipid profile, otherwise there are differences in the tendency of disease progression - which is more intense in diabetic persons - and in the quality of the lipoprotein molecules that present more atherogenic activity in the diabetics [30]; the correlation tests performed among the lipid markers (LDL, HDL, TC and TG) demonstrate the necessity of maintenance of the desirable lipoprotein indexes, like HDL for example [34], as well as the equilibrium on TG rate, which reveals that the LDL is in lower proportion. By the way, patients with potential risks to develop atherosclerosis or aggravation of diabetes must have more attention in the Family Health Program (HIPERDIA).

\section{Collaborators}

Polyane Medeiros Alves and Raiane dos Santos Pereira made the data collect and interpretation, process the initial analysis and writing the manuscript; Ariel Gustavo Letti was responsible for statistical analysis and revision and Álvaro Luís Müller da Fonseca was in charge of conception, design, final analysis, data interpretation, redaction and critical revision and approbation of the final version of the article.

\section{Acknowledgements}

We are grateful to the Department of Health of Senhor do Bonfim (SEMUS), to the Basic Health Attention Supervision and to the HIPERDIA Program Supervision for the support and permission to data collect to this research; and thanks to UNEB for financial support.

\section{References}

[1] Navarro, S.C. and Conegero, C.I. (2002) Os fatores de risco das doenças ateroscleróticas. Arq Ciênc Saúde Unipar, 6, 151-156.

[2] DATASUS (2013) Informações de Saúde (TABNET) [Internet]. Ministério da Saúde, Brasília. http://www2.datasus.gov.br/DATASUS/index.php?area $=0201$

[3] Azevedo, S., Victor, E.G. and Oliveira, D.C. (2010) Diabetes mellitus e aterosclerose: Noções básicas da fisiopatologia para o clínico geral. Revista Brasileira de Clínica Médica, 8, 520-526.

[4] Beckman, J.A., Creager, M.A. and Libby, P. (2002) Diabetes and Atherosclerosis: Epidemiology, Pathophysiology, and Management. The Journal of the American Medical Association, 287, 2570-2581. http://dx.doi.org/10.1001/jama.287.19.2570

[5] Schaan, B.D. and Reis, A.F. (2007) Doença Cardiovascular e Diabetes. Arq Bras Endocrinol Metab, 51, 151-152. http://dx.doi.org/10.1590/S0004-27302007000200002

[6] Chacra, A.R. and Alvarenga, M.A. (2008) Hiperglicemia e Doença Cardiovascular Podem Coexistir. Arq Bras Endro- 
crinol Metab, 52, 427-428. http://dx.doi.org/10.1590/S0004-27302008000300001

[7] Santos, R.D., Giannin, S.D., Fonseca, F.H., Moriguchi, E.H., Maranhão, R.C., Luz, P.L., et al. (2001) III Diretrizes Brasileiras Sobre Dislipidemias e Diretriz de Prevenção da Aterosclerose do Departamento de Aterosclerose da Sociedade Brasileira de Cardiologia. Arquivos Brasileiros de Cardiologia, 77, 1-48. http://dx.doi.org/10.1590/S0066-782X2001001500001

[8] Camacho, C.R.C., Melicio, L.A.D. and Soares, A.M.V.C. (2007) Aterosclerose, uma resposta inflamatória. Arq Ciênc Saúde, 14, 41-48.

[9] Steinberg, D. (1997) Low Density Lipoprotein Oxidation and Its Pathobiological Significance. The Journal of Biological Chemistry, 272, 20963-20966. http://dx.doi.org/10.1074/jbc.272.34.20963

[10] Sociedade Brasileira de Diabetes (2003) Consenso brasileiro sobre diabetes 2002: Diagnóstico e classificação do diabetes melito e tratamento do diabetes melito do tipo 2. Diagraphic, Rio de Janeiro, 1-72.

[11] Natarajan, S., Liao, Y., Sinha, D., Cao, G., McGee, D.L. and Lipsitz, S.R. (2005) Sex Differences in the Effect of Diabetes Duration on Coronary Heart Disease Mortality. JAMA Internal Medicine, 165, 430-435. http://dx.doi.org/10.1001/archinte.165.4.430

[12] Puernell, J.Q., Hokanson, J.E., Marcovina, S.M., Steffes, M.W., Cleary, P.A. and Brunzell, J.D. (1998) Effect of Excessive Weight Gain with Intensive Therapy of Type 1 Diabetes on Lipid Levels and Blood Pressure: Results from the DCCT. The Journal of the American Medical Association, 280, 140-146. http://dx.doi.org/10.1001/jama.280.2.140

[13] DeFronzo, R.A. (2010) Insulin Resistance, Lipotoxicity, Type 2 Diabetes and Atherosclerosis: The Missing Links. The Claude Bernard Lecture 2009. Diabetologia, 53, 1270-1287. http://dx.doi.org/10.1007/s00125-010-1684-1

[14] Goldenberg, P., Schenkmans, S. and Franco, L.J. (2003) Prevalência de diabetes mellitus: Diferenças de gênero e igualdade entre os sexos. Revista Brasileira de Epidemiologia, 6, 18-28. http://dx.doi.org/10.1590/S1415-790X2003000100004

[15] Gross, J.L., Silveiro, S.P., Camargo, J.L., Reichelt, A.J. and Azevedo, M.J. (2002) Diabetes Melito: Diagnóstico, Classificação e Avaliação do Controle Glicêmico. Arquivos Brasileiros de Endocrinologia \& Metabologia, 46, 16-26. http://dx.doi.org/10.1590/S0004-27302002000100004

[16] Arora, M., Koley, S., Gupta, S. and Sandhu, J.S. (2007) A Study on Lipid Profile and Body Fat in Patients with Diabetes Mellitus. Anthropologist, 9, 295-298.

[17] Lima, E.S. and Couto, R.D. (2006) Estrutura, metabolismo e funções fisiológicas da lipoproteína de alta densidade. Jornal Brasileiro de Patologia e Medicina Laboratorial, 42, 169-178. http://dx.doi.org/10.1590/S1676-24442006000300005

[18] Giuliano, I.C.B., Caramelli, B., Pellanda, L., et al. (2005) I Diretriz de Prevenção da Aterosclerose na Infância e na Adolescência. Arquivos Brasileiros de Cardiologia, 85, 1-3.

[19] Rover, M.R.M., Kupek, E., Delgado, R.C.B. and Souza, L.C. (2010) A Importância da Avaliação de Fatores de Risco para Aterosclerose na Infância e Adolescência-Revisão. Newslab, 102, 136-144.

[20] Onat, A. (2011) Dynamics in Cardiometabolic Risk among Turkish Adults: Similarities to that in Iranians? International Journal of Preventive Medicine, 2, 56-63.

[21] Kawamoto, R., Oka, Y., Tomita, H. and Kodama, A. (2005) Non-HDL as a Predictor of Carotid Atherosclerosis in the Elderly. Journal of Atherosclerosis and Thrombosis, 12, 143-148. http://dx.doi.org/10.5551/jat.12.143

[22] Gardener, H., Morte, D.D., Elkind, M.S.V., Sacco, R.L. and Rundek, T. (2009) Lipids and Carotid Plaque in the Northern Manhattan Study (NOMAS). BMC Cardiovascular Disorders, 9, 55. http://dx.doi.org/10.1186/1471-2261-9-55

[23] Bergmann, K. (2011) Non-HDL Cholesterol and Evaluation of Cardiovascular Disease Risk. The New England Journal of Medicine, 364, 127-135.

[24] Seon, C.S., Min, K.W., Lee, S.Y., Nho, K.W., Park, S.H., Koo, B.K. and Han, K.A. (2011) Cardiovascular Risk Assessment with Vascular Function, Carotid Atherosclerosis and the UKPDS Risk Engine in Korean Patients with Newly Diagnosed Type 2 Diabetes. Diabetes and Metabolism Journal, 35, 619-627. http://dx.doi.org/10.4093/dmj.2011.35.6.619

[25] Bianco, A., Pomara, F., Thomas, E., Paoli, A., Battaglia, G., Petrucci, M., Proia, P., Bellafiore, M. and Palma, A. (2013) Type 2 Diabetes Family Histories, Body Composition and Fasting Glucose Levels: A Cross-Section Analysis in Healthy Sedentary Male and Female. Iranian Journal of Public Health, 42, 681-690.

[26] Lotfi, M.H., Saadati, H. and Afzali, M. (2014) Prevalence of Diabetes in People Aged $\geq 30$ Years: The Results of Screening Program of Yazd Province, Iran, in 2012. Journal of Research in Health Sciences, 14, 87-91.

[27] Maruyama, C., Imamura, K. and Teramoto, T. (2003) Assessment of LDL Particle Size by Triglyceride/HDL-Cholesterol Ratio in Non-Diabetic, Healthy Subjects without Prominent Hyperlipidemia. Journal of Atherosclerosis and Thrombo- 
sis, 10, 186-191. http://dx.doi.org/10.5551/jat.10.186

[28] Vega, G.L., Barlow, C.E., Grundy, S.M., Leonard, D. and Defina, L.F. (2014) Triglyceride-to-High-Density-Lipoprotein-Cholesterol Ratio Is an Index of Heart Disease Mortality and of Incidence of Type 2 Diabetes Mellitus in Men. Journal of Investigative Medicine, 62, 345-349.

[29] Salazar, M.R., Carbajal, H.A., Espeche, W.G., Aizpurúa, M., Leiva Sisnieguez, C.E., March, C.E., Balbín, E., Stavile, R.N. and Reaven, G.M. (2013) Identifying Cardiovascular Disease Risk and Outcome: Use of the Plasma Triglyceride/ High-Density Lipoprotein Cholesterol Concentration Ratio versus Metabolic Syndrome Criteria. Journal of Internal Medicine, 273, 595-601. http://dx.doi.org/10.1111/joim.12036

[30] Vieira, E.A., Carvalho, W.A., Aras-Júnior, R., Couto, F.D. and Couto, R.D. (2011) Razão triglicérides/HDL-C e proteína C reativa de alta sensibilidade na avaliação do risco cardiovascular. Jornal Brasileiro de Patologia e Medicina Laboratorial, 47, 113-118. http://dx.doi.org/10.1590/S1676-24442011000200004

[31] Solano, M.P. and Goldeberg, R.B. (2006) Lipid Management in Type 2 Diabetes. Clinical Diabetes, 24, $27-32$. http://dx.doi.org/10.2337/diaclin.24.1.27

[32] Khawali, C., Andriolo, A. and Ferreira, S.R.G. (2003) Benefícios da Atividade Física no perfil Lipídico de Pacientes com Diabetes Tipo 1. Arquivos Brasileiros de Endocrinologia \& Metabologia, 47, 49-54. http://dx.doi.org/10.1590/S0004-27302003000100008

[33] Cockerill, G.W., Rye, K.A., Gamble, J.R., Vadas, M.A. and Barter, P.J. (1995) High-Density Lipoproteins Inhibit Cytokine-Induced Expression of Endothelial Cell Adhesion Molecules. Arteriosclerosis, Thrombosis, and Vascular Biology, 15, 1987-1994. http://dx.doi.org/10.1161/01.ATV.15.11.1987

[34] Barter, P.J. (2013) High Density Lipoprotein: A Therapeutic Target in Type 2 Diabetes. Endocrinology and Metabolism, 28, 169-177. http://dx.doi.org/10.3803/EnM.2013.28.3.169 